\title{
DRUŠTVENE TRANSFORMACIJE I PEDAGOŠKE INTERPRETACIJE POŽELJNOG ODGOJA
}

\section{Željka Pintar}

Dječji vrtić Kustošija, Zagreb

zeljka.pint@gmail.com

U radu se tematiziraju promjene pedagoških paradigmi ovisno o društveno-povijesnom kontekstu u kojemu nastaju. Svaka pedagoška ideja razrađena u društvenim dokumentima koji oblikuju rad ustanova za rani i predškolski odgoj rezultat je kolektivnog promišljanja o viziji razvoja i napretka društva. Različita povijesna razdoblja, obilježena svojim znanjima, potrebama i interesima, oblikuju sebi svojstveno političko, gospodarsko, kulturno, obrazovno okruženje. Upravo je zato razumijevanje pojedinih pedagoških paradigmi moguće jedino kroz razmatranje i uvažavanje konteksta u kojemu se provode. Budući da ne postoje univerzalne pedagoške istine, potrebno je isticati važnost istraživačkog pristupa odgojno-obrazovnoj zbilji. Uočavanje karakteristika aktualne pedagoške paradigme kroz objektivnu percepciju njezinih pozitivnih $i$ nedorečenih elemenata omogućuje njeno sustavno korigiranje na dobrobit djeteta kojemu je primarno namijenjena.

Ključne riječi: tradicionalna odgojno-obrazovna paradigma, suvremena odgojno-obrazovna paradigma, ustanova za rani i predškolski odgoj i obrazovanje

\section{Uvod}

Odgajanje djeteta povijesna je zadaća ljudske zajednice. Svako povijesno vrijeme i društveno okruženje raspolaže istinama koje smatra relevantnima za usmjeravanje svojeg cjelokupnog djelovanja, pa tako i odgojne prakse. Pedagogija se, između ostalog, određuje kao ukupnost znanja o metodama, sredstvima odgoja i naobrazbe (Anić, 2005, prema Tkalec, 2012). Ta je ukupnost znanja promjenjiva i ovisna o dosezima drugih znanosti i tekovinama društvenoga razvoja. Prijelomni znan- 
stveni ili društveno-politički događaji koji mijenjaju tendencije razvoja cjelokupnoga društva usmjeravaju i pedagoški pristup koji se prilagođava aktualnim društvenim potrebama. Pedagogija je znanost koja proizlazi iz društvenog razvoja i utječe na njega. Istraživanjima je utvrđen interaktivan odnos između odgoja i obrazovanja te društva, s tim da je utjecaj društva na odgojno-obrazovni proces intenzivniji od utjecaja tog procesa na društvo (Fagerlind i Saha, 1989, prema Pastuović, 1999). Odgoj i obrazovanje uvjetovani su društvom, djeluju na njega i u procesu su uzajamnog djelovanja, a tri glavna društvena podsustava koja su u dominantnom suodnosu s obrazovanjem su gospodarski, politički i kulturni podsustav (Pasutović, 1999). Konfliktni odgojno-obrazovni ciljevi često su u vezi s potrebama i ciljevima raznih društvenih podsustava. Ukoliko je gospodarstvu potrebna radna snaga za dominantno repetativan, industrijski rad, odgojno-obrazovnim procesom odgovarajućim za takvu društvenu potrebu ne doprinosi se razvoju ličnosti. Tržišni ekonomski sustav dovodi do povećanja socijalnih sukoba, dok socijalno ujednačavanje vodi ekonomskoj neučinkovitosti. Arhaični kulturni obrasci otežavaju političku i gospodarsku modernizaciju. U uvjetima suprotstavljenosti pojedinih tendencija društvenoga razvoja, prosvjetni se prioriteti određuju prema razvojnim prioritetima kako su ih odredile dominantne društvene skupine (Pastuović, 1999).

Pedagoške teorije raspolažu bitnim mislima koje nisu predmet egzaktnog dokazivanja, strogih provjera, detaljnih znanstvenih analiza, nego one, opravdano, proizlaze iz svjetonazornih polazišta. Praktično važna pitanja pojedinih pedagogijskih disciplina koja razmatraju odgojne, obrazovne, nastavne vrijednosti, ciljeve, načela, metode, postupke i organizacijske oblike zahtijevaju teorijski okvir do kojega se dolazi promišljanjem, a pritom nije uvijek nužna primjena znanstvenoistraživačkih metoda i postupaka (Mužić, 1999). Znanstveni aspekt se češće primjenjuje u praćenju i provjeravanju učinaka pojedinih metoda u praksi.

U smislu ovoga rada, govoreći o transformacijama društvenih sustava i mijenjanju pojedinih pedagoških paradigmi, pod paradigmom podrazumijevamo dominantan pedagoški model i obrazac djelovanja u određenom razdoblju, a odgoj i obrazovanje smatramo nerazdruživim, međuzavisnim i suovisnim procesima. Ipak, potencijalno je važno naglasiti kako pojedini autori određuju obrazovanje kao posebnu društvenu kategoriju koja je u izravnoj vezi s potrebama proizvodnje materijal- 
nih dobara, stupnjem razvoja znanosti i tehnike te s ideologijom koja u njega ugrađuje određene ciljeve (Peko, 1999). Razmatrajući pak značaj odgoja, pojedini autori navode kako je dobar odgoj onaj koji pojedinim narodima i državama osigurava međunarodni prestiž, ugled, gospodarski i kulturni razvitak, bogatstvo duhovnog života, životni standard, nacionalni ponos, sigurnost i afirmaciju (Vukasović, 1999).

\section{Društveno-povijesni kontekst i dijete}

Promjene vezane uz dijete uvijek se tiču promjena u širem društvu koje se neminovno dotiču obitelji i institucijskog okruženja odgojnoobrazovnih institucija namijenjenih djetetu. Znanja kojima određeno društvo raspolaže, vjerovanja koje podupire, običaji koje njeguje, određuju pristup djetetu. Djetinjstvo je društvena tvorevina, socijalni konstrukt određen društveno-kulturnim i povijesnim kontekstom te o djetetu možemo govoriti kao o »kulturnom otkriću« s obzirom da su različite kulture »izmislile« različitu djecu (Tomanović, 1996). Iako je $u$ fokusu ovoga rada promatranje tradicionalne i suvremene odgojne paradigme $\mathrm{u}$ institucionalnom kontekstu namijenjenom djeci rane $\mathrm{i}$ predškolske dobi, važno je sustavno povijesno pratiti mijenjanje ophođenja prema djetetu kao specifičnom pripadniku zajednice, sukladno s pripadajućom promjenom šireg društvenog konteksta. Svako društveno ophođenje prema djetetu može se shvatiti i protumačiti jedino u odnosu na određeno društveno, ekonomsko, kulturno okruženje. Pojedine odgojno-obrazovne politike nemoguće je promotriti dekontekstualizirano - samo investiranje u obrazovanje djece može se shvatiti kao ulaganje u dječji razvoj ili kao ulaganje u društvenu kontrolu; može se shvatiti kao podrška djeci ili kao kapitalizacija djetinjstva, odnosno organiziranje dječjeg života u skladu s određenim društvenim potrebama (Qvortrup, 1995). Za uvid u smislenost određenih određenja odgoja i obrazovanja, važno je razumjeti društvenu motivaciju koja ih generira.

U povijesnom razmatranju, pojedina razdoblja unificirano se proglašavaju kao djeci više ili manje naklonjena. Generalizirajući, pojedini se periodi proglašavaju u potpunosti pozitivnim ili izričito negativnim po dijete. Tako se, gledajući historijski, srednjovjekovno razdoblje često ističe i potencira kao veoma negativno raspoloženo prema djetetu. Tom se povijesnom kontekstu obično pripisuje zakidajuće ophođenje prema populaciji djece. Prema Ariesu, to je razdoblje obilježilo emocionalno 
zastupanje djece ravnodušnošću odraslih (Nikolić Jakuš, 2015). Navedena se teza svojedobno shvaćala općeprihvaćenom i uživala je široku podršku znanstvenih krugova i javnosti. Ariesova analiza tumači kako u Srednjem vijeku ne postoji ideja djetinjstva kao posebne faze ljudskoga života što se dokazuje sekundarnim povijesnim izvorima - ikonografijom, književnošću i pisanim dokumentima te se navodi kako se otkriće djetinjstva događa tek postepeno u razdoblju od 16. do 18. stoljeća (Tomanović, 1996). Tvrdi se kako su djeca u srednjovjekovnom razdoblju shvaćana kao umanjeni odrasli te da se djetinjstvo kao specifična faza čovjekova razvoja negira (Hameršćak, 2004). Prema Ariesovim sljedbenicima, to je razdoblje zanemarene djece. Istovremeno, nastoji se prikazati kako je kroz povijest ideja djetinjstva sustavno razvijana sve do današnjeg vremena koje doživljava svoju kulminaciju u iskazivanju emotivne topline odraslih spram djece (Nikolić Jakuš, 2015). Međutim, navedene su teze mnogostruko polemizirane. Neki autori smatraju kako se pristupu razvoja koncepta djetinjstva ne mora pribjeći kao jednoobraznom kretanju prema sve savršenijim oblicima, već je potrebno uvažiti i istodobnost raznovremenog. Tako se primjerice odnos prema djeci u Francuskoj u 17. stoljeću istodobno odvijao kroz ideju da su djeca bića za zabavu i da su bića koja uz mukotrpan trud treba osloboditi od grijeha i privesti spasenju (Hameršak, 2004). Također, nakon 1980ih pojavila su se istraživanja koja su pokazala da je snažna emocionalna povezanost djece i odraslih kroz povijest stabilna (Hameršak, 2004). Iako se iz današnje perspektive srednjovjekovni savjeti o njezi djeteta mogu smatrati neprikladnima ili čak opasnima, tumači se da su bili motivirani brigom i ljubavlju prema djetetu. Oprimjerujući navedeno, izlaže se kako srednjovjekovna praksa slanja novorođenčeta dojilji na selo nije bila motivirana težnjom distanciranja od djeteta kako je to prvotno tumačeno, već se gradski zrak smatrao potencijalno opasnim po zdravlje, a kolostrum se od antike poimao zdravstveno štetnim za dijete pa su roditelji veliku pažnju posvećivali potrazi za odgovarajućom dojiljom, izražavajući pritom ljubav i skrb prema svojemu potomstvu (Nikolić Jakuš, 2015).

Dijete predindustrijskog doba obično se predstavlja kao obiteljska radna snaga. Navodi se kako predindustrijsko razdoblje obilježavaju velike familijske jedinice, zadruge, višegeneracijske, sociološke i ekološke cjeline patrijahalnog tipa (Benvin, 1972). U predindustrijsko doba, osobito u tradicionalnoj ruralnoj zajednici, proširena obitelj zajedno sa seoskom sredinom obavljala je biološko-fizičku funkciju 
(rađanje, ekonomska aktivnost, zaštita članova) te kulturnu, socijalnu i emocionalnu funkciju (Puljiz, 1994). Obitelj je tada činila čvrstu cjelinu života, mali socijalni mikrokozmos. Mjesto stanovanja podudaralo se s mjestom privređivanja te se sav život odvijao na posjedu zadruge ili sela. Dijete je bilo uključeno u sve radne aktivnosti te se smatralo proizvodnom radnom snagom koja svojim radnim doprinosom potpomaže roditelje. Iako se nastoji potencirati činjenica kako je dijete predindustrijskog doba bilo proizvodno dobro, neki autori navode kako je u tom razdoblju dijete bilo shvaćeno prvenstveno kao obiteljsko blago, obogaćenje i počašćenje roditelja (Benvin, 1972).

Usporedno s razvojem urbano-industrijskog društva ekonomska funkcija obitelji počinje se odvijati izvan nje same (Puljiz, 1994), a uloga edukacije i socijalizacije značajnim dijelom seli iz obitelji (Bosanac, 1976, prema Puljiz, 1994). Deagrarizacija i urbanizacija uzrokovala je korjenite promjene u proizvodnji i načinu života ljudi. Sada obitelj postaje dvogeneracijska, obiteljski život više nije tipiziran, očekuje se da dvoje slobodnih i odgovornih ljudi izgrađuju svoj program u oblikovanju obitelji. Počinju se oblikovati prve institucije za skrb o djeci zaposlenih roditelja. Započinje faza institucionalnog djeteta. Na području Republike Hrvatske počinju se oblikovati dječja zabavišta (Mendeš, 2015). U Zagrebu je prva takva ustanova osnovana 1869. godine, a širenjem mreža ustanova za predškolsku djecu objavljuje se Rukovođ za zabavišta u kojemu se navodi kako zabavište budi i razvija djetetove sposobnosti te se dijete boravkom u ustanovi priprema za pučku školu (Mendaš, 2015). Također se napominje kako zabavište ne rješava roditelje njihovih uzgojnih dužnosti i prava, nego ih s njima dijeli (Cvijić, 1895, prema Mendaš 2015). Uspjeh industrijske revolucije, znanosti i tehnologije razvio je opće uvjerenje da se može kretati samo naprijed te se činilo kako znanost ima odgovor na sve. Tako se i odgajanje djece počelo zasnivati na zdravim tehničkim načelima. Kako je industrijska proizvodnja zahtijevala regularnost, ponavljanje i planiranje, smatralo se da je djecu potrebno izvrgnuti planskom odgoju u čvrsto rutiniziranom procesu (Weatherill, 1994). No, kao što je vidljivo u skladu s dostupnim saznanjima i uvjerenjima, već se tada zagovarao pun djetetov psihosocijalni napredak potaknut njegovim životom u instituciji te se podržavala uspostava suradničko-partnerskih odnosa s obitelji.

Daljnji društveno-gospodarski razvojni tijek obilježava treća industrijska revolucija, oko 1970. godine, okarakterizirana uporabom elek- 
troničkih i informacijsko-komunikacijskih sustava temeljem kojih se vrši automatizacija u proizvodnim procesima. Neki autori naglašavaju i četvrti industrijski obrat predstavljen u Njemačkoj 2011. godine, a označen daljnjom digitalizacijom i umrežavanjem svih funkcija unutar tvornice i izvan nje te robotizacijom procesa proizvodnje (Nikolić, 2017). Te su prijelomnice društvenih prilika značajno utjecale na odgojno-obrazovni institucionalni pristup djetetu. Vodeći se sada idejom kako upravo obrazovni sustav mora poteći od gospodarstva i zahtjeva tržišta rada (Nikolić, 2017), pedagoški stručnjaci osmišljavaju odgojno-obrazovni proces prikladan takvim društvenim obilježjima. Društvo budućnosti predviđa kako će se u sferu tržišta rada sve više uključivati roboti koji će zamjenjivati radnike te će se razviti zahtjev za novim zanimanjima s različitim znanjima i vještinama, što će utjecati na život ljudi i promjene u njihovom ponašanju. Suvremena obrazovna politika povodi se tim načelom. Odgoj za nepredvidivu budućnost stvara suvremen odgoj u suvremenoj ustanovi - organizaciji koja uči.

\section{Suvremeni i tradicionalni društveni ustroj te dijete rane i predškolske dobi}

Suvremeni dječji vrtić afirmira dijete na način svojstven aktualnom društvu. Suvremeno europsko društvo zainteresirano je za omogućavanje i osiguranje svojeg gospodarskog razvoja. Europske stope gospodarskog rasta pokazuju se manjima od američkih i kineskih pa Europa stoga osmišljava strategiju za ekonomski napredak koji se temelji na postavljanju znanja i inovacija kao temelja gospodarskog razvoja. Svjesna kako njezinu prevlast ugrožavaju SAD i Kina, Europa osmišljava načine zadržavanja visokog životnog standarda uz sve oskudnije prirodne resurse (Grgurić, 2011). Znanje postaje osiguravajući čimbenik koji jamči društveni progres - ono je glavna proizvodna snaga i uvjet uspješnosti ljudskog društva (Deklaracija o znanju - Hrvatska temeljena na znanju i primjeni znanja, HAZU, 2004). Suvremeno društvo proziva se društvom znanja koje se održava permanentnim učenjem; informacijskim društvom u kojemu se svaki napredak ostvaruje oplemenjivanjem i širenjem znanja i informacija (Deklaracija o znanju, 2004). Prelazak u društvo znanja i transformacija znanja na višoj tehnološkoj razini zahtijeva dobro promišljen i organiziran sustav cjeloživotnog obrazovanja. Europsko vijeće 2000. godine na sastanku u Lisabonu zaključilo je kako treba definirati nove temeljne vještine koje je potreb- 
no steći cjeloživotnim učenjem kao ključnu mjeru europskog odgovora na globalizaciju (Preporuka europskog parlamenta i savjeta; ključne kompetencije za cjeloživotno učenje, 2010). Navedena Preporuka teži doprinijeti razvoju kvalitetnog, prema budućnosti usmjerenog obrazovanja, izrađenog prema potrebama europskog društva. U tome se smislu navode ključne kompetencije potrebne svim pojedincima za osoban razvoj i društvenu integraciju. Kompetencije koje je Europska komisija odredila kao osam ključnih za osobni i profesionalni razvoj svakog pojedinca su komuniciranje na materinskom jeziku u pisanom i usmenom obliku, komuniciranje na stranim jezicima, matematička pismenost i osnove kompetencije iz znanosti i tehnologije, sposobnost korištenja digitalne tehnologije, umijeće organiziranja učenja i raspolaganja vremenom, društvena i građanska kompetencija, inicijativnost i poduzetništvo te kulturna svijest i izražavanje (Preporuka EK, 2006, prema Račić, 2013). Kako se smatra da je važan razlog neostvarivanja punog potencijala gospodarskog rasta ujedinjenog europskog tržišta naglašeno zaostajanje u usvajanju novih tehnologija u gospodarstvu (Jurlin, Samardžija i Basarec-Sertić, 2018), napominje se kako je u obrazovanju potrebna snažna orijentacija na treću industrijsku revoluciju te se u tu svrhu trebaju jače naglasiti fundamentalne prirodnoznanstveno-matematičke osnove suvremenog tehnologijsko-informatičkog razvoja (Deklaracija o znanju, 2004). Obrazovanje se promišlja u viziji stvaranja inovativnog društva i gospodarstva te su odgojno-obrazovne ustanove nositelji i pokretači razvoja ljudskih potencijala (Strategija obrazovanja, znanosti i tehnologije, NN, 2014). Ipak, u ovakvim polazištima neki autori razabiru podređivanje znanja principima tržišne ekonomije (Liessmann, 2008). Radi se o kapitalističkom pristupu znanju - znanje nije cilj, nego sredstvo koje ne zahtijeva nikakva promišljanja dok su opravdana za tržište ili rast gospodarstva. Autori također naglašavaju sadržajne razlike termina informacije, spoznaje i znanja.

Terminološki promatrano, suvremeno se društvo, kako je navedeno, proziva društvom znanja. Ciljem odgojno-obrazovnog sustava smatra se razvoj kompetencija. Definirajući kompetencije navodi se kako one podrazumijevaju kombinaciju znanja i njegove primjene; zbir vještina, stavova i odgovornosti pomoću kojih je pojedinac osposobljen za obavljanje određenog posla (Račić, 2013). Dakle, znanje je sastavnica kompetencije koja je sadržajno obuhvatnija. No, zaključujući konsenzualno može se ustvrditi kako društvo znanja obuhvaća stvaranje uvjeta za brzo apsorbiranje postojećeg znanja, stvaranje novih te efikasnu pri- 
mjenu znanja za unapređenje proizvodnje i ukupnog života i rada neke zajednice (Matijević, 2011).

U kontekstu cjeloživotnog učenja i u domeni ranog i predškolskog odgoja i obrazovanja suvremeni odgojitelj fokusiran je na kompetencije koje dijete društva znanja treba razvijati. Odgojitelj strukturira stimulativno okruženje u kojemu dijete ima slobodu istraživanja i stjecanja znanja, osigurava izbor i potiče istraživačke aktivnosti djece te olakšava učenje, ali njime ne upravlja (Ellis, 2004, prema Slunjski, 2011). Dijete nije objekt u odgojnom procesu, nego je socijalni subjekt koji participira, konstruira i u velikoj mjeri određuje svoj vlastiti život i razvoj (Nacionalni kurikulum za rani i predškolski odgoj i obrazovanje, MZOS, 2014). Učenje se smatra subjektivnim procesom konstruiranja znanja koje se izvana može samo potaknuti, ali se njime ne može izravno upravljati jer se ono u različitim subjektima učenja ne događa istim redoslijedom niti istom brzinom (Nacionalni kurikulum za rani $i$ predškolski odgoj i obrazovanje, MZOS, 2014). Promovira se djetetova samoinicijativnost i zagovara učeća autonomija.

Opisujući nasuprot tome tradicionalni vrtić, vrtić socijalističkog razdoblja, navodi se kako je djetetova pozicija u njemu bila pasivna, receptivna i obespravljena te je odgojno-obrazovni proces bio u službi razvoja djetetove prilagodljivosti, poslušnosti, prilagođenosti i receptivnosti (Slunjski, 2011). Tradicionalni pristup naziva se tlačiteljskom pedagogijom, ugnjetavanjem, neprikladnim pristupom koji stvara neravnotežu u duši osobe, a uz nedovoljni razvitak potencijala, pojedinac stvara iskrivljeni identitet i nedovoljno samopoštovanje (Gregory, 2003, prema Slunjski, 2011). U tradicionalnom su odgoju djeca bila objektificirana, obespravljena, deprivilegirana, uskraćena za samostalno i kritičko razmišljanje i odlučivanje. Kontrola u tradicionalnoj predškolskoj praksi bila je pretjerana i održavala je strah od slobode i izazova, dok je odgojitelju davala sigurnost u dobro obavljen posao (Milanović, 2014). U takvom je procesu, u skladu s biheviorističkom psihološkom teorijom i empirijskom analitičkom paradigmom, dijete promatrano kao sirov materijal koji se putem specijalno propisanih strategija transformira u određeni produkt (Miljak, 1996). Odgojitelj je, umjesto na dijete, orijentiran na sadržaj podučavanja (Slunjski, 2011). Naglašavanjem usmjerenosti tradicionalnog odgojitelja prema sadržajima učenja, stvara se privid kako su odgojitelji bili orijentirani na sadržaje, nevezano uz ciljeve procesa i sposobnosti koje su djeca u njemu trebala razvijati. 
Nasuprot tome, suvremeni se odgojitelj ne koncentrira na sadržaje učenja, nego na okruženje za učenje. U fokusu nije djetetovo stjecanje znanja, nego razvoj kompetencija. Umjesto razmatranja sadržaja učenja, prioritetna zadaća suvremenog odgojitelja stvaranje je podržavajućeg okruženja za učenje. On ne promatra ostvarenost ciljeva odgoja u odnosu na razvojne zadaće, prvenstveno je zaokupljen ishodima učenja. Nastoji se također istaknuti kako je u nadvladanim oblicima tradicionalnog odgoja cilj odgojno-obrazovnog procesa bio dominantno društveno uvjetovan, dok suvremena vizija odgoja i obrazovanja u središe procesa stavlja samo dijete (Strategija obrazovanja, znanosti i tehnologije, NN, 2014). Međutim, teze o važnosti suvremenog odgojno-obrazovnog procesa kojime se stvara ljudski potencijal spreman za izgradnju konkurentnog društva ne upućuju na njegovu društvenu nezavisnost te je uopće mogućnost stvaranja društveno bezinteresnog odgoja veoma upitna.

Proučavajući pak dokumente koji usmjeravaju tradicionalnu i suvremenu pedagošku praksu - Program odgojno-obrazovnog rada $u$ dječjem vrtiću (Zavod za prosvjetno pedagošku službu SR Hrvatske, 1979) i Nacionalni kurikulum za rani i predškolski odgoj i obrazovanje (MZOS, 2014) - vidljivo je kako se oba dokumenta pozivaju na znanstvene spoznaje na kojima temelje svoj pristup institucionalnom odgoju. Oba dokumenta također izražavaju zalaganje za cjelokupan razvoj djeteta. Tako Program zagovara utjecanje na razvoj intelektualnih sposobnosti i interesa djeteta; omogućavanje stjecanja elementarnog znanja o prirodi, životu i radu ljudi; razvijanje radoznalosti i bogaćenje djetetova iskustva; razvijanje djetetova stvaralaštva i elementarnog smisla za estetsko doživljavanje i izražavanje; zadovoljavanje potrebe za igrom i zajedničkim druženjem u krugu vršnjaka uz osiguravanje zdravog i vedrog djetinjstva; pridonošenje pripremi djeteta za školu uz suradnju s osnovnom školom radi postizanja kontinuiteta u odgoju i obrazovanju djece; surađivanje s obitelji u primjenjivanju suvremenih metoda u odgoju i zdravstvenoj njezi djeteta; surađivanje s mjesnom zajednicom, društvenim i drugim organizacijama radi afirmacije predškolskog odgoja uopće. U tome smislu, oba dokumenta, uz promoviranje cjelokupnog i svestranog razvoja djeteta, naglašavaju važnost suradnje s osnovnom školom radi osiguravanja kontinuiteta obrazovanja, zalažu se za suradnju s lokalnom zajednicom i ističu važnost suradnje $\mathrm{s}$ roditeljima u odgojno-obrazovnom procesu. No, jedno od osnovnih načela Kurikuluma jest fleksibilnost odgojno-obrazovnog procesa, a 
nepostojanje takve fleksibilnosti često se ističe kao manjkavost Programa. Program uistinu potencira važnost dosljednog ritma aktivnosti tijekom dana, međutim naglašava i kako svi zahtjevi koji se postavljaju pred djecu i pravila kojih se moraju pridržavati moraju biti djeci dostupni, u skladu s njihovim potrebama i mogućnostima, kako bi se djeca u vrtiću osjećala ugodno. Suvremena paradigma zahtijeva odgojitelja kao indirektnog poticatelja učenja djece i kritizira dominaciju tradicionalnog odgojitelja. Međutim, Programom je tradicionalni odgojitelj upućen da sudjelovanje djeteta u odgojiteljski vođenoj aktivnosti treba biti djetetu interesantno. U odgojiteljski potaknutoj aktivnosti materijali i sredstva trebaju biti raznovrsni, fabula djetetu bliska i interesantna, a postupci trebaju poticati angažman djece (Program odgojno-obrazovnog rada u dječjem vrtiću, Zavod za prosvjetno pedagošku službu SR Hrvatske, 1979). Govoreći o ulozi odgojitelja u igrama i aktivnostima djece, Programom se napominje kako je i u stvaralačkim igrama uloga odgojitelja postojana, iako indirektna, jer između suvišnog miješanja u djetetovu igru i ravnodušnog promatranja postoji široko područje razumnog upravljanja.

Motivacija uspostave i programska obilježja tradicionalne prakse ne impliciraju da je tada odgojitelj imao pogrešan ili nedobronamjeran pristup djetetu, kako se iz pozicije suvremene paradigme često implicira. Važno je uvažiti da promjene društvenih prilika u tradicionalnom razdoblju posljedično utječu i na pristup odgojno-obrazovnoj praksi. Smatra se kako su promjene predškolskih programa između 1965. i 1980. bile potaknute orijentacijom društva prema tržišnoj ekonomiji u okvirima društvene svojine i radničkog samoupravljanja, dok su zakoni o predškolskom odgoju nastali između 1980. i 1990. vezani uz socijalističko samoupravljanje i udruženi rad (Babić i Irović, 1999). Jednako tako, osnivanjem samostalne Republike Hrvatske i razvojem demokratskog društva započinju i nove intencije u odgojno-obrazovnoj praksi osmišljene u Programskom usmjerenju odgoja i obrazovanja djece predškolske dobi (Glasnik Ministarstva prosvjete i kulture, 1991). Razmatrajući zakonske odredbe vezane uz pedagošku praksu, stječe se dojam da je odgojitelj svakoga razdoblja pozvan ophoditi se prema djetetu angažirano i skrbno, uz njegovo puno poštivanje. Odgojitelji su stručno i profesionalno obvezni podržavati cjelokupni razvoj i sveopću dobrobit djeteta, no tome cilju doprinose na načine karakteristične za društveno okruženje u kojemu se njihova zadaća realizira. 


\section{Učeće društvo i suvremeni dječji vrtić}

Iako je terminološki koncept organizacije koja uči veoma istaknut u opisivanju potrebnih obilježja suvremene odgojno-obrazovne institucije, navedeni idejni nacrt osmišljen je za svaku suvremenu radnu organizaciju. Uslijed globalizacije poslovanja, velikih promjena u okruženju, ubrzanog tehnološkog razvoja, ekonomskih, socijalnih i političkih nejednakosti između razvijenih i nerazvijenih zemalja te ekoloških problema, bilo je potrebno osmisliti koncept koji označava pomak u načinu razmišljanja i poimanja stvarnosti. Pod tim se pojmom podrazumijeva organizacija u kojoj ljudi neprestano razvijaju svoje mogućnosti kako bi došli do željenih rezultata, a pritom se njeguju novi i otvoreni modeli mišljenja, kolektivne su težnje slobodne i ljudi neprestano uče kako učiti zajedno (Senge, 1990, prema Rupčić, 2007). Pet je ključnih disciplina u građenju učeće organizacije: osobno usavršavanje, sistemsko mišljenje, prepoznavanje mentalnih modela, timsko učenje, stvaranje zajedničke vizije (Galić, 2010). Organizacija koja uči konstantno teži proširenju svojih sposobnosti, a u cilju ostvarenja superiornih performansi što se postiže fundamentalnom promjenom razmišljanja i percepcije članova (Galić, 2010). Ukoliko tradicionalna organizacija želi prerasti u organizaciju koja uči, potrebna je veća zastupljenost timskog rada, smanjivanje hijerarhije, prenošenje odgovornosti te sposobnost obavljanja višestrukih zadaća.

U kontekstu razvoja europskog gospodarstva važno je da poduzeća brzo prilagođavaju svoju strukturu kako bi ostala konkurentna i u tome smislu potreban je njihov razvoj u vidu učećih organizacija (Preporuka europskog parlamenta i savjeta; ključne kompetencije za cjeloživotno učenje, 2010). Poduzeće koje uči organizacija je koja ima uključene sustave, mehanizme i procese pomoću kojih se na osnovi učenja povećava sposobnost ostvarivanja održivih konkurentskih prednosti (Rupčić, 2007). U tehnološko-gospodarskom kontekstu govori se i o tvornicama koje uče. Pametna tvornica ona je koja se brzo prilagođava novonastalim situacijama u okruženju, reagira na promjenjive zahtjeve tržišta, fleksibilna je i transformativna, personalizira proizvode individualno se prilagođavajući svojem tržištu (Nikolić, 2018). U odgojno-obrazovnom diskursu preuzimaju se svi elementi kojima ovaj koncept raspolaže i apliciraju se na sve sudionike odgojno-obrazovnog procesa. Teorija učeće organizacije postaje model po kojemu se razvija i dječji vrtić. Kako bi se objasnili kriteriji kvalitete predškolskih ustanova, u Priruč- 
niku za samovrednovanje ustanova za rani i predškolski odgoj i obrazovanje (Slunjski et al., 2012) navode se kriteriji ekvivalentni teoriji organizacije koja uči. Uz navođenje vrtićkih posebnosti, poput prostorno-materijalnih i tehničkih te zdravstveno-higijenskih uvjeta rada i uz isticanje obilježja kurikuluma i odgojno-obrazovnog procesa kao specifikuma vezanog uz odgojno-obrazovne ustanove ranog i predškolskog odgoja, Priručnik se vjerno izvodi iz navedenog koncepta. Neke posebnosti suvremene pedagoške paradigme, kao što su definiranje implicitne teorije, naznačavanje važnosti dokumentiranja procesa učenja djece ili potenciranje važnosti refleksivnog prijatelja, indirektno se deriviraju iz tog idejnog predloška. Primjerice, navodi se kako je u poduzeću kojemu se kao sustavu dogodilo organizacijsko učenje veoma važno da pojedinci budu voljni i spremni iznijeti svoje individualne mentalne modele, suočiti ih s mentalnim modelima svojih kolega, raspraviti o mogućim razlikama i tijekom rasprave doći do unificirane percepcije o tome što sustav jest, kako djeluje i kakvi su odnosi relevantnih dijelova (Rupčić, 2007). Jednako tako, u odgojno-obrazovnoj sferi navodi se kako je važno stvarati uvjete u kojima će odgojitelji imati priliku upoznavati i osvještavati vlastite vrijednosti, kao i vrijednosti svojih kolega, o njima raspravljati i postupno ih mijenjati i usklađivati rukovođeni zajedničkom vizijom (Slunjski, 2006). Rasprave odgojitelja služe razotkrivanju odgojiteljevih implicitnih teorija (Miljak, 1996). Isto se navodi kao bitno u komunikaciji djece i odgojitelja. Važno je dokumentirati aktivnosti djece audio i video zapisima, transkriptima razgovora, raznim oblicima dječjih ekspresija, poput crteža te navedeno koristiti u zajedničkim raspravama djece i odraslih u kojima oni zajednički i recipročno uče (Slunjski, 2006).

U kurikulumu svojstvenom organizaciji koja uči dokida se podjela učenja na dvije strane te su svi participanti istodobno i učenici i učitelji, a proces učenja djeteta obilježen je samoinicijativnošću i samoorganizacijom uz prepuštanje djeci da upravljaju vlastitim učenjem i da za njega preuzimaju odgovornost (Slunjski, 2006). Kako se navodi, u organizaciji koja uči zadaća vođa je konstruiranje procesa učenja u kojemu će se pojedinci moći produktivno nositi s raznim pitanjima razvijajući svoja umijeća u disciplinama učenja (Senge, 2001). Međutim, za razliku od poduzeća ili tvornica koje uče, u dječjem vrtiću uspostavljaju se odgovorno neravnopravni odnosi - upravo je odrasla osoba zadužena za kvalitetu uspostavljenog odnosa s djetetom kroz koji se događa odgojno-obrazovni proces. Autori upozoravaju na današnju poteškoću 
određivanja granice između djetinjstva i odrasle dobi te govore o nestanku djetinjstva u suvremenom društvu (Postman, 1994). Razjašnjava se kako odgojno-obrazovna autonomija djeteta podrazumijeva njegovu odgovornost za vlastiti razvoj, a upravo je djetinjstvo ustanovljeno kao doba razvoja u kojemu je dijete oslobođeno od odgovornosti za osobni razvoj i socijalne odnose (Juul, 2005, prema Bašić, 2011). Nedosljedan pristup djetetu čitljiv je i iz dokumenata i koncepata na kojima se zasniva rad odgojno-obrazovnih ustanova. Konvencija o pravima djeteta važno je polazište Nacionalnog kurikuluma za rani i predškolski odgoj i obrazovanje (MZOS, 2014), a tumačeći sliku djeteta i djetinjstva koja se navedenim dokumentom zagovara, autori uočavaju određenu nekoherentnost (Kopić i Korajec, 2010). Konvencijom se, naime, naglašava dječje pravo na autonoman izbor, odlučivanje, djelovanje, slobodu mišljenja. S druge se pak strane ističe važnost zaštite, skrbi i odgovornosti odraslih za djecu. Istovremeno se djeca opisuju kao ranjiva, a djetinjstvo kao razdoblje u kojemu je za njih najvažnija uloga odraslih, dok se $s$ druge strane naglašava važnost djetetova aktivna sudjelovanja $u$ društvu, čime se ono nastoji tumačiti kao ravnopravno s odraslima.

Suvremena paradigma tako raspolaže s na prvi pogled proturječnim zahtjevima i suočava odraslog s novim dvojbama - treba li u ophođenju prema djetetu prevladavati kontrola ili spontanost odraslog, treba li se odgojitelj ponašati kao dijete ili kao odrasli, treba li na djetetovo ponašanje reagirati promišljeno ili intuitivno, čini li dobrog odgojitelja kontrola ili kaos (Milanović, 2014)? Istovremeno, u razdoblju samoinicijativnog djeteta, pitanje treba li odgojno-obrazovnim pristupom razvijati poslušnost ili inicijativnost djeteta, želimo li da dijete ima čvrst vanjski (pravilo, zahtjev, zabranu) ili unutarnji autoritet (samostalno i odgovorno biranje onoga što će reći, odlučiti, učiniti), odbacuje se kao suvišno (Slunjski, 2011). Iako suvremena pedagogija zagovara neospornu važnost poticanja djetetove autonomije, važno je ipak naglasiti kako je odgoj autoritativnog tipa koji se ostvaruje restriktivnim i odgovornim ponašanjem odraslog uz mnogo topline i razumijevanja istraživački potvrđen kao optimalan pristup djetetu (Brajša-Žganec, 2003). Djetetu je potreban pouzdan vanjski autoritet i odgojni model. Upravo pomoću modela iz svoje okoline djeca usvajaju prosocijalne vještine ili vještine povezane s djetetovim socijalizacijskim problemima (BrajšaŽganec, 2003). Govoreći o prosocijalnosti u kontekstu tradicionalnog odgoja, navodi se kako je tadašnji odgoj ohrabrivao brigu za druge i udovoljavanje drugima, a obeshrabrivao osamostaljivanje u brizi o sa- 
mome sebi i zauzimanje za sebe samoga (Milanović, 2014). Takva se konstatacija ipak čini proturječnom, naime, briga za druge podrazumijeva osposobljenost za brigu o samome sebi. Ohrabrivanjem djeteta da pomogne drugome zapravo izražavamo vjeru da je ono sposobno biti osobno odgovorno i pobrinuti se za sebe samokomunicirajući svoje potrebe.

Kompleksnost odgojnih pitanja nepotrebno je reducirati i relativizirati jednostavnim ili-ili odgovorima na prividno, za suvremeni kontekst, banalna pitanja. Također, svaka odgojiteljeva ponašajna isključivost potencijalno je za dijete štetna; odrasla osoba treba biti sposobna disponirati razne modalitete svoga ponašanja, prilagođavajući ih potrebama djeteta i modificirajući ih ovisno o zahtjevima situacije i karakteristikama okolnosti.

Organizacija koja uči kritizirana je s moralnog, teoretskog, instrumentalnog i političkog aspekta (Rupčić, 2007). Osvrćući se na navedeni model, neki autori ističu da je osmišljen u cilju univerzalne promjene organizacija neovisno o tipu te da zbog toga ne uzima dovoljno u obzir kontekstualna ograničenja i kulturne specifičnosti pojedinih organizacija (Rupčić, 2007). Jednako tako, pristup je definiran prilično apstraktno i idealistično bazirajući se na filozofskoj raspravi, bez strategijskih smjernica što bi trebalo učiniti da bi se taj koncept proveo. Unatoč popularnosti koncepta organizacije koja uči, može se uočiti kako nema definicije tog idejnog nacrta s kojom bi se složili svi autori, pa se zbog toga poseže za metodom distinkcije koja omogućuje navođenje što neka pojava nije prije nego se odredi što ona jest (Rupčić, 2007). Metoda distinkcije koristi se u i obrazlaganju karakterističnosti suvremene odgojno-obrazovne ustanove. Prilikom objašnjenja suvremene institucije ranog i predškolskog odgoja autori navode da je ona negacija tradicionalne, da dokida njezinu pojavnost i osporava njezinu vrijednost. Iznoseći njihova obilježja, autori ističu nadmašivost suvremenih odgojno-obrazovnih ustanova u odnosu na one prevladane. Tradicionalne ustanove su manjkave i »pogrešne« u pristupu djetetu. Suvremena paradigma suprotstavlja se tradicionalnoj osporavajući i, štoviše, omalovažavajući prevladane metode odgoja djeteta. Pritom se zanemaruje kako se pedagoška ideja uvijek promišlja u ovisnosti o prostorno-vremenskome kontekstu koji je podložan razvoju i mijeni i u objašnjavanju i tumačenju određenih pedagoških paradigmi nužno je uvažiti navedeno. 
Izbjegavanjem pedagoškog centrizma i razumijevanjem relativnosti određenih pedagoških istina, otvara se put boljem shvaćanju aktualnih obrazaca odgojno-obrazovne prakse. Ukoliko se suvremena paradigma neprestano opravdava usporedbom s tradicionalnom, stvara se mogućnost da je prihvatimo kao bolju alternativu, umjesto da uočavamo njezina vlastita pozitivna i negativna obilježja kako bismo potakli njezin razvoj.

\section{Zaključak}

Odgojno-obrazovne svrhe i zadaće uvjetovane su kulturom, tradicijom, filozofskim pogledima, političkim odnosima, religijskim shvaćanjima, vrijednosnim usmjerdbama, postignućima znanosti i tehnike, gospodarskom i društvenom razvijenošću (Vukasović, 1999). Način shvaćanja odgoja i obrazovanja ponajprije proizlazi iz potrebe očuvanja svekolikog ljudskog duhovnog i egzistencijalnog nasljeđa konkretne društvene formacije i uvijek je beziznimno usko povezan sa zamislima cjelokupnoga društva, njegovim usmjerenjima, funkcijama i zadaćama te vizijom uloge pojedinca u specifičnom povijesnom okruženju (Mijatović, 1999). Usporedno s društvenim promjenama, mijenjaju se i odgojna nastojanja.

Tradicionalna i suvremena paradigma suprotstavljene su u svojim polazištima pristupu djetetu rane i predškolske dobi u odgojno-obrazovnom procesu. Obrazlažući suvremenu paradigmu i objašnjavajući njezine prednosti spram djeteta u odnosu na tradicionalitet, autori često zauzimaju kritički negativan argument prema prevladanim obrascima odgajanja djece. No, vrlo je važno pritom naglasiti da je zapravo nemoguće razumjeti odgojnu praksu bez razumijevanja konteksta u kojemu se ona provodi. Upravo društvene okolnosti strukturiraju odgoj prikladan aktualnim potrebama i viziji budućnosti zajednice. Odgoj je društvena stvar, rezultat i posljedak socijalnih okolnosti. Mijenjanjem ekonomskih, gospodarskih, političkih tendencija u društvu, mijenja se i pristup odgojnoj praksi. Promatrajući zakonske odredbe kojima se uređuje odgojno-obrazovna praksa u odgojno-obrazovnim institucijama namijenjenima djetetu rane i predškolske dobi, zamjetljivo je kako političko-gospodarska promjena okolnosti dovodi do promjena tendencija u odgojno-obrazovnoj sferi koje se društvenim dokumentima zagovaraju. Manipulira se poželjnim posljedcima odgojno-obrazovnog procesa ovisno o perspektivi razvoja društva. Svako povijesno vrijeme raspola- 
že uvjerenjem da živi ili omogućuje život na najbolji način. Pritom je najbolji način onaj koji je određenom društveno-povijesnom okruženju dostupan u smislu znanja, vjerovanja, uvjerenja. Zbog toga se kritika prevladanih paradigmi bez uvažavanja, obrazlaganja i poštivanja povijesnog konteksta u kojemu se one zbivaju čini neopravdanom.

Povijesno gledano, način na koji su odrasli razumijevali dijete bio je određen važećim istinama određenog vremenskog i prostornog miljea, specifičnom kulturom. Promatranje poimanja djeteta kroz povijest važno je kako bi se naglasila potreba izbjegavanja pedagoškog centrizma i pribjegavanja istinama koje samo iz određene pozicije možemo smatrati valjanima. Odgovarati dakle na pitanje što je za dijete dobro može se samo u okviru sasvim konkretnih sociokulturalnih uvjeta i tijeka razvoja društva i kulture (Bašić, 1999). Kako je naglašeno, povijesno razmatranje položaja djeteta u perspektivama različitih društava pokazuje razvojnu dimenziju djetetove pozicije i shvaćanja njegove dobrobiti. Iz tog je razloga u svakom razmatranju pedagoške prakse, neovisno iz kojeg vremenskog razdoblja ona potječe ili u kojemu se odvija, važno omogućiti pedagoški diskurs otvoren za kritičko promišljanje odgojno-obrazovne zbilje. Odgojno-obrazovnu stvarnost i pojavnost određenih pedagoških praksi važno je šire kontekstualno uvažavati. Kompleksnost odgojno-obrazovnih pristupa nemoguće je svoditi na jednoobrazne istine. Pedagoški centrizam lako dovodi do distanciranja od povijesno drukčijeg pojedinca, a kako je povijest strana zemlja gdje se stvari čine drukčije (Hartley, 1953, prema Nikolić Jakuš, 2015), promatranje drugih svjetonazora kao bitno drukčijih od naših potencijalno dovodi i do nerazumijevanja drukčijeg u sadašnjosti (Nikolić Jakuš, 2015). Smatrati kako je tradicionalna odgojna paradigma bila manipulativna prema djetetu u odnosu na suvremenu, nije sasvim točno. Svaki odgojni pristup na neki način oblikuje, manipulira djetetovim kapacitetima kako bi dijete razumjelo principe svoga društvenog okruženja i oblikovalo sposobnosti potrebne svojoj zajednici. Demokratski odnos odraslih i djece također je društveno osmišljen pristup potreban društvu u perspektivi i viziji njegova budućega razvoja. Način na koji se individua osobno ostvaruje, afirmira u zajednici, ovisi o karakteristikama toga okruženja. Stoga i trenutna pedagoška misao treba osvještavati svoju relativnost. Osvješćujući nadvladivost trenutne pedagoške istine, ostvaruje se mogućnost kritičke rasprave o trenutnim tendencijama odgoja što je nužno za njihov razvoj i za dobrobit djece kojima su namijenjene. 


\section{Literatura}

Babić, Nada i Irović, Stanislava (1999), »Ciljevi institucionalnog predškolskog odgoja u Hrvatskoj od 1945. do 1990. godine«, Dijete, vrtić, obitelj, 5(17), str. 3-9.

Bašić, Slavica (1999), »Odgoj«, u: Mijatović, Antun (ur.), Osnove suvremene pedagogije, Zagreb: Hrvatsko pedagoško-književni zbor, str. 177-201.

Bašić, Slavica (2011), »Nova slika djeteta u pedagogiji djetinjstva«, u: Maleš, Dubravka (ur.), Nove paradigme ranog odgoja, Zagreb: Filozofski fakultet Sveučilišta u Zagrebu, str. 19-37.

Benvin, Anton (1972), »Obitelj kroz povijest«, Bogoslovska smotra, 42(1), str. 35-51.

Brajša-Žganec, Andreja (2003), Dijete i obitelj: emocionalni i socijalni razvoj, Jastrebarsko: Naklada Slap.

Grgurić, Ivan (2011), »Europe 2020 - europska strategija za pametan, održiv i uključiv razvoj«, Revija socijalne politike, 18(1), str. 119-124.

Galić, Marin (2010), »Učeće organizacije«, MediAnali: međunarodni časopis za pitanja medija, novinarstva, masovnog komuniciranja i odnosa s javnostima, 4(7), str. 179-194.

Glasnik Ministarstva prosvjete i kulture (1991), Programsko usmjerenje odgoja i obrazovanja djece predškolske dobi, Zagreb: Ministarstvo prosvjete i kulture.

Hameršak, Marijana (2004), »Desetljeća Ariesove povijesti djetinjstva«, Časopis za suvremenu povijest, 36(3), str. 1061-1078.

[HAZU] Hrvatska akademija znanosti i umjetnosti (2004), Deklaracija o znanjuHrvatska temeljena na znanju i primjeni znanja, Zagreb: Hrvatska akademija znanosti i umjetnosti.

Jurlin, Krešimir; Samardžija, Višnja i Basarec-Sertić, Martina (2018), Konkurentnost, pametna specijalizacija i investicije u novim državama članicama EU-a i Hrvatskoj, Zagreb: Institut za razvoj i međunarodne odnose - IRMO.

Kopić, Željka i Korajac, Valerija (2010), »Djeca i djetinjstvo u dokumentima o pravima djece«, Život i škola, 24(2), str. 45-54.

Liessmann, Konrad Paul (2008), Teorija neobrazovanosti. Zablude društva znanja, Zagreb: Naklada Jesenski i Turk.

Matijević, Milan (2011), »Kakvo znanje trebamo za društvo znanja«, u: J. Strarec (ur.), Zbornik prispevkov: Međunarodna znanstvena konferenca, Novo Mesto: Fakulteta za poslovne in upravne vede i Visoka šola za upravljanje in poslovanje, str. 44-49. 
Mendeš, Branimir (2015), »Početci institucijskog predškolskog odgoja u Hrvatskoj i njegova temeljna obilježja«, Školski vjesnik: časopis za pedagogijsku teoriju i praksu, 64(2), str. 227-250.

Mijatović, Antun (1999), »Razvoj suvremenih pedagoških ideja«, u: Mijatović, Antun (ur.), Osnove suvremene pedagogije, Zagreb: Hrvatski pedagoškoknjiževni zbor, str. 13-39.

Milanović, Mirjana (2014), Pomozimo im rasti: priručnik za partnerstvo odgojitelja i roditelja, Zagreb: Golden marketing - Tehnička knjiga.

Miljak, Arjana (1996), Humanistički pristup teoriji i praksi predškolskog odgoja. Model Izvor, Velika Gorica: Persona.

Mužić, Vlado (1999), »Pedagogijska znanost i njena određenja«, u: Mijatović, Antun (ur.), Osnove suvremene pedagogije, Zagreb: Hrvatski pedagoškoknjiževni zbor, str. 101-129.

[MZOS] Ministarstvo znanosti, obrazovanja i sporta (2014), Nacionalni kurikulum za rani i predškolski odgoj i obrazovanje, Zagreb: Ministarstvo znanosti, obrazovanja i sporta.

Nikolić, Gojko (2017), »Industrija i obrazovanje«, Andragoški glasnik, 21(1-2), str. 37-48.

Nikolić, Gojko (2018), »Je li industrija 5.0 odgovor na industriju 4.0 ili njen nastavak?«, Polytechnic and Design, 6(2), str. 1-8.

Nikolić Jakuš, Zrinka (2015), »Povijest djetinjstva u srednjem vijeku i povijest emocija: osjećaji roditelja prema djeci kao primjer istraživačkog pristupa temi osjećaja u prošlosti«, Historijski zbornik, LXVIII(2), str. 377-381.

[NN] Narodne novine (2014), Strategija obrazovanja, znanosti i tehnologije, Narodne 124/2014 (24. 10. 2014.).

Pastuović, Nikola (1999), »Temeljne zakonitosti odgoja i obrazovanja«, u: Mijatović, Antun (ur.), Osnove suvremene pedagogije, Zagreb: Hrvatski pedagoško-književni zbor, str. 49-175.

Peko, Anđelka (1999), »Obrazovanje«, u: Mijatović, Antun (ur.), Osnove suvremene pedagogije, Zagreb: Hrvatski pedagoško-književni zbor, str. 203-223.

Petrović-Sočo, Biserka (2009), »Značajke suvremenog naspram tradicionalnog kurikuluma ranog odgoja«, Pedagogijska istraživanja, 6(1-2), str. 123-138.

Postman, Neil (1994), The Disappearance of Childhood, New York: Vintage Books.

Preporuka europskog parlamenta i savjeta; ključne kompetencije za cjeloživotno učenje (2010), Metodika, 11(20), str. 169-182.

Program odgojno-obrazovnog rada u dječjem vrtiću (1979), Zagreb: Zavod za prosvjetno pedagošku službu SR Hrvatske. 
Puljiz, Vlado (1994), »Socijalna politika i obitelj«, Revija za socijalnu politiku, $1(3)$, str. 237-244.

Qvortrup, Jens (1995), »Childhood and modern society: A paradoxical relationship?«, u: Brannen, Julia i O’Brien, Margaret (ur.), Childhood and Parenthood, London: Institut of Education, str. 189-199.

Račić, Marta (2013), »Modeli kompetencija za društvo znanja«, Suvremene teme: međunarodni časopis za društvene $i$ humanističke znanosti, 6(1), str. 86100.

Rupčić, Nataša (2007), »Kritički osvrt na koncept organizacije koja uči«, Društvena istraživanja: časopis za opća društvena pitanja, 16(6), str. 1239-1261.

Senge, Peter M. (2001), Peta disciplina, Zagreb: Mozaik knjiga.

Slunjski, Edita (2006), Stvaranje predškolskog kurikuluma u vrtiću - organizaciji koja uči, Zagreb: Mali profesor.

Slunjski, Edita (2011), Kurikulum ranog odgoja, istraživanje i konstrukcija, Zagreb: Školska knjiga.

Slunjski, Edita; Ljubetić, Maja; Pribela Hodap, Sonja; Malnar, Ana; Kljenak, Tatjana; Zagrajski Malek, Snježana; Horvatić, Sanja i Antulić, Sandra (2012), Priručnik za samovrednovanje ustanova ranoga i predškolskog odgoja i obrazovanja, Zagreb: Nacionalni centar za vanjsko vrednovanje obrazovanja.

Tkalec, Zdravko (2012), »Pedagogija poduzetništva i cjeloživotno učenje«, Učenje za poduzetništvo, 2(2), str. 21-26.

Tomanović, Smiljka (1996), »Detinjstvo u istoriji - između ideje i prakse«, Sociologija, XXXVIII(2), str. 41-52.

Vukasović, Ante (1999), »Svrha i zadaće odgoja i obrazovanja«, u: Mijatović, Antun (ur.), Osnove suvremene pedagogije, Zagreb: Hrvatski pedagoškoknjiževni zbor, str. 129-148.

Weatherill, Rob (1994), Cultural Collapse, London: Free Assn Books. 


\section{SOCIAL TRANSFORMATIONS AND PEDAGOGICAL INTERPRETATIONS OF THE PREFERRED EDUCATION}

\section{Željka Pintar}

This paper discusses the changes in pedagogical paradigms depending on the socio-historical context in which they occur. Each pedagogical idea elaborated in the social documents that shape the work of early and pre-school institutions is the result of collective reflection on the vision of development and advancement of society. Different historical periods, marked by specific knowledge, needs and interests, form distinctive political, economic, cultural, and educational environments. It is precisely for this reason that understanding individual pedagogical paradigms is possible only through consideration and appreciation of the context in which they are carried out. As there are no universal pedagogical truths, it is necessary to emphasize the importance of a research approach to current educational system. Observing the characteristics of the current pedagogical paradigm through objective perception of its positive and imprecise elements allows its systematic correcting that focuses on the welfare of the child to whom it is predominantly intended for.

Key words: traditional educational paradigm, contemporary educational paradigm, institution for early and pre-school education 